\title{
Co-Production from the Viewpoint of Design and Computing Education Development
}

\author{
Solvita ZARINA \\ Faculty of Computing, University of Latvia, \\ 19 Raina Blvd., Riga, LV-1586, Latvia \\ ORCID: 0000-0001-8884-2971
}

solvita.zarina@.lu.lv

\begin{abstract}
This paper focuses on an interdisciplinary approach to finding similarities of problems and their solutions as well as how both governmental institutions and educators of design and computing can deal with service and social design, co-production, and co-creation of public services. The paper provides an empirical analysis of several case studies, one of which was a coproduction session held by a governmental institution and students of the Faculty of Computing at the University of Latvia. The conclusion marks a possible future scenario involving the process of co-production with students from design and computing, as well as other relevant departments, thus helping to engage young citizens, and at the same time future professionals in a better delivery of public services.
\end{abstract}

Keywords: co-production, education, design, user experience, public services

\section{Introduction}

Industry-university collaboration and co-production, involving co-creation with communities and governmental institutions is one of the possible further scenarios to combat current challenges within design and computing education. In addition, co-production allows students professional engagement as citizens improving public service delivery for society well-being.

Paper begins with historical aspects of design for social well-being (Fuller, 1969; Papanek, 1971). Further on, this paper provides insight into how ideas of co-production and co-creation developed, providing a historical background of both service design and citizen involvement that were used in the delivery of public services.

In the 21st century, a paradigm shift of design curriculum has involved significant changes towards digital services and design for social well-being, instead of previously dominating product design for mass consumption. Changes have encompassed the involvement of the general public as end users and encouraged updates in the design process. Many digital services have become complex IT systems, and they all have to be designed in a user-centered manner. Fulfilment of this complex task is better implemented through teamwork, by using design thinking and service design tools 
within close co-creation or collaboration with end users, which requires an additional knowledge set.

A paradigm shift of design curriculum also introduces some topical questions in design education (Norman, 2010). Co-production (Koretsky et al., 2014) and design thinking are seen as tools in contemporary computing and engineering education, too (Dym et al., 2005; Atman et al., 2014). This study develops preliminary concept about co-production as one of the possible contemporary methods to broaden design curriculum for computing and design students in achieving better educational results.

Methodology chapter provides an empirical analysis using two case studies, one of which was a co-production session held by the Ministry of Environmental Protection and Regional Development of the Republic of Latvia and students within the Faculty of Computing from the University of Latvia.

The results were that students demonstrated a high level of engagement and creativity during co-production sessions. They also held dual roles as citizens, as well as future information and communications technology (ICT) professionals, and graphical user interface (GUI) designers.

The conclusion section indicates further field of research points to a possible extension of this study, putting it into a wider theoretical context. It marks a potential future scenario, involving students from computing, design, as well as other relevant departments in the co-production sessions. Not only would this help to achieve better study results, but it also would provide an opportunity to help engage young citizens in a better delivery of public services.

The following chapters deal with a theoretical framework and literature review, research methodology, results and conclusion.

\section{Theoretical Framework and Literature Review}

This section refers to historical aspects of design for social well-being and emergence of the co-production concept. It also addresses development of contemporary design education, as well as computing and engineering education concepts used to better fulfill EQANIE (European Quality Assurance Network for Informatics Education, Europe) and ABET (Accreditation Board for Engineering and Technology, Inc., USA) accreditation criteria. Following the conceptual development of these disciplines, we can trace how uniting them all together may facilitate to design a system for better public service delivery using co-production methodology.

\subsection{Historical Background of Socially Responsible Design}

Design as a term became more widely used at the beginning of the 20th century, and then it was mainly applied to product and graphic design (Meggs, 2016, Droste, 1990). Simultaneously, designers had also dealt with the topical needs of people through trying to help them overcome social vulnerability from the very beginning of design development. Bauhaus design school (Germany, 1918-1933) has to be mentioned as one of the pioneers with its socially responsible design concept (Droste, 1990).

Buckminster Fuller, an American architect, designer and systems theorist, and Victor Papanek, American-Austrian designer and educator, are supposed to be the early well-known designers and design thinkers who started shaping the whole domain of this field. In his "Operating Manual for Spaceship Earth" (1969), Fuller relates the planet 
Earth to a spaceship, a technological wonder all people are responsible to maintain. $\mathrm{He}$ continues by saying that our living on this planet as humankind overall was never coordinated or instructed from above. Fuller sees our responsibility to continue operations on the "Spaceship Earth" to prolonging satisfactory survival and growth, both physically and metaphysically (Fuller, 1969).

In his collection of essays, "Design for the Real World. Human Ecology and Social Change" (1971), Papanek pays attention to the fact that design has become the most powerful tool in environmental and societal planning. He expands this concept by saying that planning as a design process is the basis of all human activities. He also calls for socially and morally responsible design in regards to products that meet the needs of society, instead of merchandise designed for mass consumption (Papanek, 1971).

In the late 1970s, Dieter Rams, an outstanding German production designer (he worked more than 40 years for Brown and Vitsoe) defined "Ten Good Design Principles", part of which directly dealt with sustainable and responsible design concepts. Among the innovative, aesthetic and elaborative aspects, he suggested that good design has to make a product useful, be understandable and long lasting, honest, unobtrusive, and environmentally friendly. He also admitted that, "Good design is as little design as possible" (Rams, 1976). These principles of good design practice are still relevant in screen design systems today and they populate interaction design online resources (Garreta-Domingo, 2020; Hermosilla, 2018). The "Ten Good Design Principles" are currently part of interface design education (Maiden, 2011; Boyer, 2014). In addition, several authors generalize these principles by applying them to the basic principles of universal design (Rapp, 2014).

\subsection{Co-Production Concept. Service and Social Design}

The co-production concept emerged in the 1970s and early 1980s. Citizen involvement was recognized as an important part of designing the public service. (Ostrom et al, 1978). Gordon P. Whitaker was one of the first to use the co-production concept to explain the active involvement of the society as the recipient of services (Whitaker, 1980). Elaine B. Sharp complemented this concept by also defining it as the joint product of society and government professionals (Sharp, 1980).

These ideas, expressed in the 1970s and 1980s, once again demonstrated their importance at a time when user interface design problems were beginning to evolve (Galitz, 2007). The IDEO Company (USA) was founded in 1991, and by 2001, they began to focus more on consumer experiences. Later, the company became increasingly involved in social and service design. To deal with the user involvement and promotion of cooperation, IDEO developed the concept of design thinking, which they explained as an opportunity for designers, as well as non-professional designers to use design tools to solve various product and service development problems. They applied design thinking, using co-designing and co-creation as the methods (WEB, a). In 2015, IDEO published a human-centered design manual ${ }^{1}$ and made it available online for all interested.

Service design was first introduced as an academic field in design research and education in the early 1980s (Shostack, 1984). This term covers the entire service or user journey, instead of user experience about one touchpoint, one product, or resource

\footnotetext{
${ }^{1}$ The Field Guide to Human-Centered Design https://www.designkit.org/
} 
(Gibbons, 2017). Besides being user-centered, evidencing (visualizing service experiences) with key moments (sequences) in a user's journey, and forming a holistic experience, it uses a wider set of tools than before, including customer journey maps and service blueprints. An important part of service design is a principle of co-creation, which refers to the involvement of both customers and those who are part of a system or a service (WEB, b).

Today, designers feel increasing responsibility for their products and services to address clients' problems in a sustainable way. To communicate with their clients in a better manner, one of the most popular methods in use is the "Double Diamond" framework with its four development steps: discover, define, develop, and deliver, and its iterative approach. It was launched in 2004 by London Design Council (WEB, c). The shift to design thinking and the popularity of socially responsible complex problem solving, rather than only visually amazing product or graphic design, further increases the demand for co-creation and co-production. In addition, industrial designers face recent changes in consumers' trends, demanding for more socially responsible solutions.

In the twenty-first century, design plays an important role in initiating and shaping social change and innovation, according to Italian designer, educator, and author Ezio Manzini. He finds a place and a role in this new design paradigm for both professional design experts and anyone interested (Manzini, 2015).

Due to the development of design thinking and service design, the design education curriculum is undergoing change. In addition to traditional skills, training is needed in a number of interdisciplinary areas.

\subsection{Design Education Change}

Recent transition towards a user-centered design approach and the emergence of design thinking, challenge the role and norms of traditional design. Transition also introduces some topical questions in design education. In his essay, "Why Design Education Must Change" (2010), Donald Norman challenges a longstanding practice of design education. He admits that so far, physically usable products have been created in design, especially in industrial design. Nowadays, a large number of designers create different types of service design, solving organizational and social problems. As a result, designers need new skills, such as a background in behavioral science. However, current design education does not provide an opportunity to acquire these skills in a systematic way (Norman, 2010).

Not only do these changes in design curriculum require a focus on interdisciplinary collaboration, but also the core concepts of a designer as maker are about to change. Acquiring necessary technical and artistic skills was and still is one of the foundations of graphic and industrial design education. With the emergence of strategic and service design, this unshakable concept shifts towards design thinking and problem solving as an equally important body of knowledge. Thus, this emergence is pushing the boundaries of what design can be and do (Norman and Klemmer, 2014). Together with an experiential learning, design educators see service learning (Bowie and Cassim, 2016) and community engagement (Shea, 2011) as a part of contemporary design curriculum. Besides design and industry collaboration practice, interdisciplinary engagements have become increasingly more appreciated and necessary in design education (Self et al., 2019). 


\subsection{Constructivist Framework in Computing and Engineering Education}

Design education-related contemporary problems and challenges are not isolated from computing and engineering education and education in general. To achieve better learning outcomes, contemporary educational theories advise to consider a constructivist framework to educate students. Teaching based on constructivism seeks to construct students' knowledge with the active participation of the learners themselves (Newsletter and Swinicky, 2014). In addition to the acquisition of knowledge, learning process stands for the importance to acquire skills in problem solving, and working collectively (Margulieux et al., 2019).

In this framework, problem-based learning (PBL) strategies are often used. The PBL concept first developed in the 1970s to follow the need for new types of knowledge and skills in the industry, and has since evolved (Smith et al., 2005). This concept is based on two aspects.

- First, students are usually scheduled to work in groups. Students need to develop a solution and instructors act as facilitators and coordinators (Prince and Felder, 2006). Student groups should be well informed about advantages as well as problems that may occur. In order to achieve excellent results, a group of students must become a team of students (Oakley et al., 2004).

- $\quad$ Second, the problems students need to solve can be ill-defined or ill-structured real-world problems, instead of addressing well-defined classroom tasks (Kolmos and de Graaf, 2014).

One of the co-production projects discussed in the next section reveals how the fifth semester students within the Faculty of Computing from the University of Latvia (FC UL) helped to solve the real-world problems applying their preliminary gained knowledge. From the very beginning of their studies, computer engineering students at the FC UL are taught using the PBL strategies. After a semester long internship ${ }^{2}$, most of the students maintain a working relationship with the IT industry employers.

\subsection{Resume}

Previously mentioned metaphor of our planet Earth related to a spaceship without an operating manual (Fuller, 1969) now should be related both to the material world and previously non-existing virtual world. According to Osborne et. al., governmental institutions started to evolve from bureaucratic model in which the client is not the center of attention. Nowadays it has developed to the era of the New Public Governance which also should involve a "public service dominant" approach. (Osborne, 2012). Co-production and co-creation concept developed and reached far more engaged audiences. Beside university-industry collaboration, design and engineering educators use experiential learning and PBL concepts as a better way of teaching their curriculum. However there is a gap between governments - universities collaboration for better public service delivery. Co-production could be one of the methods to use to bridge this gap.

\footnotetext{
${ }^{2}$ The internship is a mandatory part of FC UL study program curriculum. According to study plan, students are offered a choice from 80 to 100 Latvian and international ICT companies and institutions.
} 
The next section reveals how the real-world problems can be solved using co-production methodology.

\section{Case Studies of Co-Production Methods}

\subsection{Background and Context}

This section focuses on two co-production case studies that could serve as a pilot projects for the next step in the development of an improved collaboration among university students, governmental institutions responsible for the delivery of public services, and society members who are supposed to use these services. These projects were chosen due to their problem scale and topicality, as well as sustainability (Hic et Nunc project) and possibility to improve UX of the core digital services delivery at the state level (a co-production session to improve state service portal latvija.lv). In both cases the co-production method was implemented as an answer to society needs providing an opportunity to the group of students' team-up for solving a real-world problem.

The first project Hic et Nunc ("Here and Now", 2016) took place in Zurich-Oerlikon Messehalle 9 (Exhibition hall No. 9) in Switzerland as a response to topical society need facing refugee crisis. It was developed as a co-production between Zurich University of Arts (ZHdK) and Zurich based Government Agency for Immigrant Integration (AOZ), and asylum seekers from Eritrea, Syria, Afghanistan and Iraq. Between January 2016 and the end of 2019 around 250 people lived in the Messehalle 9. Four people at a time lived in one of the prefabricated residential container-like blocks, and four of these units shared a small kitchen. Thirty-nine undergraduate students at ZHdK under the supervision of their professors Antonio Scarponi, Karin Seiler and Martin Bölsterli were responsible for designing ready-to-use products and services to improve living conditions for this socially vulnerable multinational refugee group, comprising people of different ages.

Second project, a co-production session-produced by the Ministry of Environmental Protection and Regional Development of the Republic of Latvia (VARAM) and facilitated by the European Union (EU) project Empowering Citizens to Transform European Public Administrations (CITADEL) team, and performed by students of FC UL-reveals co-production of students and a governmental institution to improve a state service. The state service portal latvija.lv has been developed since 2006. As a state portal, it follows web design standards defined at the Procedures for Institutions to Post Information on the Internet ${ }^{3}$. In total, six co-production sessions were conducted working with four other focus groups: non-governmental organization (NGO) members; people with special needs (visually challenged); employees of the United State and Municipal Client Service Centers (CSC); and inhabitants - users of the latvia.lv portal (Zeibote et. al., 2018).

\footnotetext{
${ }^{3}$ Regulations of the Cabinet of Ministers No. 445. Available at: https://likumi.lv/ta/id/316109kartiba-kada-iestades-ievieto-informaciju-interneta
} 


\subsection{Hic et Nunc project}

Hic et Nunc project collaborative scenario was based on mutual respect and equality. In this case, a refugee group took a client role. Thus refugees were encouraged to overcome their differences in cultural and social backgrounds to formulate their topical demands. ZHdK students had an opportunity to work with multinational clients in different age groups. Initially surprised about service and social design and co-production, refugees came up with their concept. They wanted real improvements instead of paperwork only, within a limited period of four weeks. According to Scarponi, these project requirements served as an ideal assignment for students from a different curriculum e.g. product designers, interaction designers, etc. (WEB, d).

As it can be seen from the Road $\mathrm{Map}^{4}$, students applied design thinking and iterative approach to meet the expected outcomes. First they defined the context of interior spaces in the Messehalle, marking it as a temporary shelter for three to eight month time period for an individual refugee. Then they raised topics for further work on (a) space and language, (b) activation of space, and (c) Messehalle's role in the city. Students and their professors also defined the main condition for better fulfilment of their design task, "a lack of formal social work education", thus indirectly confirming contemporary design education challenges.

ZHdK professors' used group work strategy and students were divided into teams of four people. To fulfill the given task, the client's allocated four-week time period was divided in equally long time segments for (a) concept, (b) implementation, (c) prototype, and (d) communication phases. Students and the project facilitators-their professorsworked together on product design for interior space improvements taking into account (a) ergonomics, (b) multifunctionality and (c) modularity of furniture design. They also used cognitive approach creating a German language learning system. They defined, "space as a learning vehicle" by developing illustrated physical dictionary in the collective indoor spaces. For each design solution, its authors were publicly recognized and took full responsibility for the result. Students' work results were evaluated by project tutors and the project partners: AOZ and the clients - a group of refugees (WEB, e).

\subsection{Co-Production Session with FC UL Students}

To engage with co-production series with the objective of improving access to the services provided by Latvian state institutions and municipalities through the state service portal latvija.lv, VARAM and CITADEL project Latvian team had developed methodological guidelines. They applied the "Brainstorm Rules" from the IDEO Web Design Kit; "Idea Dashboard" and "Check-in check-out" methods. The team also used the elements of the "Six Thinking Hats" co-production method. (Zeibote et. al.) The CF UL Professor Solvita Zarina was acquainted beforehand with the methodology of coproduction session to allow discussion with students about their voluntary participation. About 60 percent of the fifth semester students decided to participate. Before the session, the moderator from VARAM shortly presented CITADEL project and ideas this project addressed.

\footnotetext{
${ }^{4}$ Available at: https://www.hic-et-nunc.me/methode
} 
According to the project CITADEL information (WEB, f), four priority topics and practical tasks for each session were prepared in collaboration among the controller of the portal, a subordinate institution of the ministry - the State Regional Development Agency (VRAA) and CITADEL project Latvian team consisting mainly of Centre for European and Transition Studies (CETS) UL researchers, also with a guidance from user involvement expert from IMEC 5 .

Students' task was to conduct the usability and user experience (UX) tests of the portal, and to identify problems of mobile device GUI. The FC UL fifth semester students' prerequisite knowledge include learning outcomes from Software Engineering, Web Technologies I, II, and Introduction to Web Design courses ${ }^{6}$. It gave them opportunity to perform role of an expert.

Students as well as other focus groups tested:

1) Life Situations; 2) E-Services; 3) Catalogue of Public Services; 4) Client Workplace (My Working Place).

The main criteria for defining the usability of the portal in the context of client satisfaction were:

1. Convenience of portal's design visual perception. How visually attractive is the portal's home page? How does one improve it?

2. Structure of information, transparency of placement and convenience for navigation. How easy is it to understand and where is navigation located in the portal? How does one improve it?

3. Speed. How fast can one make necessary actions in current information structure? How does one improve it?

4. Clarity of the service description. How clear are the descriptions of accessible services? Is it possible to understand the information that one is looking for? How does one improve it?

5. Convenience of search function use. How convenient is the search function? Is it working precisely? How does one improve it? (WEB, f)

During the session, its moderator divided students into smaller groups (four to five people in each). These groups performed five parallel tasks. Students evaluated their user experience applying the abovementioned testing assignments on the portal user interface, using only smartphones as well as contributed to discussions. A coproduction session was monitored by five external observers who were responsible for the written collection of students' comments and proposals.

After the co-production session, Professor Solvita Zarina provided an elective assignment questionnaire with four suggested categories to give feedback on students' user experience and to offer recommendations for improvements. Students were asked to evaluate (a) Landing Page; (b) Client Workplace; (c) their success to accomplish the particular task they performed together with group members during the co-production session; (d) at the last section students were prompted to provide a summary of their overall portal's UX assessment.

The abovementioned student activities paved the way to the results further detailed in the next section.

\footnotetext{
${ }^{5}$ IMEC is a R\&D and innovation hub in nanoelectronics and digital technology. Available at: https://www.imec-int.com

${ }^{6}$ The course descriptions covering the learning outcomes of the curriculum are available at: https://www.lu.lv/en/gribustudet/study/bachelors-study-programmes/bachelor-computer/
} 


\section{Results}

\subsection{Hic et Nunc}

1. To improve the refugees living conditions, the Hic et Nunc project immediate results included (a) the creation of a separate women's space and (b) other semi private room development, with (c) a visual German language learning system seamlessly incorporated into furniture and interior elements, (d) a simple gym, as well as public spaces like (e) a library. Product designs, such as (f) benches, serving also as charging stations for mobile phones, $(\mathrm{g})$ the stowage systems and $(\mathrm{h})$ modular shelves were made to provide more everyday comfort at the asylum center (Seiler et al., 2018).

2. In 2017, the Hic et Nunc team received the first prize at Hochparterre ${ }^{7}$ competition Die Besten 2017 (“The Best 2017"). Project as well as reached international recognition when participating in exhibition devoted to Social design at the Museum für Gestaltung (Museum of Design) Zürich, Switzerland (2018) and the Museum für Kunst und Gewerbe (Museum of Art and Design) Hamburg, Germany (2019), and being represented in the exhibition catalogue.

3. The interdisciplinary design module has been implemented at the Department of Design 2019 ZHdK curriculum. The fourth semester students have the opportunity to work in interdisciplinary teams on issues related to the development of districts and cities.

4. The project is followed up by two recent sub-projects Radio Fogo and Pop Up Kitchen.

The project shows that future designers can successfully work together with refugee groups and government agencies. Students emphasized the need to be aware that we all live in one place, and that by working as designers they can improve the living conditions of all groups in a society. The students were ready to show civic activity in solving the consequences of the global crisis rather than confining their activity to the "academic comfort zone" (WEB, g).

\subsection{Co-Production Session with FC UL Students}

1. Students showed a high level of engagement during the co-production session. To foster the State service portal latvija.lv public service the FC UL students proposed 69 improvements in total ${ }^{8}$. The most common was the demand for mobile friendly GUI providing a positive user experience. They gave their opinion about various subjects, such as language and usability in certain places, in particular, Landing Page and Search.

2. About half of the students ${ }^{9}$ who participated in the co-production session, later evaluated the overall usability of digital service in their voluntary written comments. The structured assignment gave them an opportunity for further reflection on the UX problems dealing with a complex structure of service portal design. The outcomes of submitted assignments provided another data set for the co-production partners.

3. During the session and following it, students performed a dual role as citizens as well as future ICT professionals, using their knowledge in front-end web development and design to improve GUI and UX of the state service portal.

\footnotetext{
${ }^{7}$ Publishing house for architecture, planning and design. Available at: https://www.hochparterre.ch/

${ }^{8}$ These data were obtained from the observer questionnaire statistics.

${ }^{9}$ Data were obtained from the UL e-learning system.
} 
4. Recently the implementation of CITADEL project recommendations has made an immediate impact at the state level. According to VARAM, the improved state level digital public services played crucial role as a technical solution during COVID-19 crisis when numerous municipalities in Latvia had to close their physical service centers (WEB, h). This solution continues providing functioning of state services during the autumn 2020.

\section{Conclusion}

In the both case studies, all participant groups involved have experienced direct benefits from using the co-production method. In the first case study participated ZHdK students and professors, a governmental organization (AOZ), and extremely diverse social groups (asylum seekers from Eritrea, Syria, Afghanistan and Iraq). In the second case study took part FC UL students and their professor, governmental organizations (VARAM and VRAA), CITADEL project Latvian team, and various social groups (NGO members, people with special needs, employees of the CSC, and users of the latvia.lv portal). These co-production projects encouraged mutual respect and equity among all project members (Hic et Nunc), and provided an equally extensive insight into digital service delivery to participants and their moderators, and allowed decision-making for students as citizens and young professionals (a co-production session with FC UL students).

This paper, using a small set of data is only a preliminary study. In the future, it could be expanded as a broader cross-disciplinary research. University students may be a significant focus group in the co-production of public services in fields such as computing, design, communication, cognitive sciences, and psychology. They are also emerging active citizens as well as future specialists.

Contemporary design process equally demands problem solving ideation, maker's skills, iterative and agile prototyping phases, as well as includes co-creation and co-production with socially meaningful value. These case studies provide a complex yet positive answer to the engineering and design education change, allowing students to learn the designing process as a holistic experience. These young minds have the capacity to ask uncomfortable questions and to provide unexpected answers, thus solving problems and helping the government to transform public administration, as well as contributing greatly to communities and society in general.

\section{Acknowledgments}

This paper has been partly supported by the European Union's Horizon-2020 research and innovation program under grant agreement 726755 , and partly supported by the Laboratory for Innovative Information Technologies at the Faculty of Computing, University of Latvia. 


\section{References}

Atman, C., Eris, O., McDonnell, J., Cardella, M., Borgford-Parnell, J. (2014). Research, Practice, and Examples that Link the Two. In: Johri, A. and Olds, B. (Eds.), Cambridge Handbook of Engineering Education Research. Cambridge University Press, Cambridge, 201-226.

Bowie, A., Cassim, F. (2016). Linking classroom and community: A theoretical alignment of service learning and a human-centered design methodology in contemporary communication design education. Education as Change, 20(1), 126-148. https://doi.org/10.17159/19479417/ $2016 / 556$

Boyer, M. (2014). The 10 Principles of Good Web Design for Developers, available at https://flatironschool.com/blog/the-10-principles-of-good-web-design-for

Droste, M. (1990). Bauhaus 1919-1933. Taschen, Köln.

Dym, C., Agogino, A., Eris, O., Frey, D., Leifer, L. (2005). Engineering Design Thinking, Teaching, and Learning. Journal of Engineering Education, 94(1), 103-120. DOI: 10.1002/j.2168-9830.2005.tb00832.x.

Fuller, B. (1969). Operating Manual for Spaceship Earth. Southern Illinois University Press, Carbondale, IL.

Garreta-Domingo, M. (2020). Dieter Rams: 10 Timeless Commandments for Good Design, available at https://www.interaction-design.org/literature/article/dieter-rams-10-timelesscommandme nts-for-good-design

Galitz, W. (2007). The Essential Guide to User Interface Design: An Introduction to GUI Design Principles and Techniques. John Wiley \& Sons, Inc., Hoboken, NJ.

Gibbons, S. (2017). Service Design 101, available at https://www.nngroup.com/articles/servicedesign-101

Hermosilla, L. (2018). Dieter Rams: 10 principles of Good Design applied to UX design, available at https://uxdesign.cc/dieter-rams-10-principles-of-good-design-applied-to-ux-design-a4a45d aedebb

Kolmos, A. and Graaff, E. (2014). Problem-Based and Project-Based Learning in Engineering Education. In: Johri, A. and Olds, B. (Eds.), Cambridge Handbook of Engineering Education Research. Cambridge University Press, Cambridge, 141-160.

Koretsky, M., Gilbuena, D., Nolen, S., G. Tierney G., Volet, S. (2014). Productively engaging student teams in engineering: The interplay between doing and thinking. 2014 IEEE Frontiers in Education Conference (FIE) Proceedings, 1-8. DOI: 10.1109/FIE.2014.7044434.

Maiden, N. (2011). Requirements and Aesthetics. IEEE Software, 28 (3), 20-21. DOI: 10.1109/MS.2011.60

Manzini, E. (2015). Design, When Everybody Designs. An Introduction to Design for Social Innovation. MIT Press, Cambridge, MA.

Margulieux, L., Dorn, B., Searle, K. (2019). Learning Sciences for Computing Education. In: Fincher, S. and Robins, A. (Eds.), The Cambridge Handbook of Computing Education Research. Cambridge University Press, Cambridge, 208-230.

Meggs, P. and Purvis, A. (2016). Meggs' History of Graphic Design. John Wiley \& Sons, Inc., Hoboken, NJ.

Newstetter, W. and Svinicki, M. (2014). Learning Theories for Engineering Education Practice. In: Johri, A. and Olds, B. (Eds.), Cambridge Handbook of Engineering Education Research. Cambridge University Press, Cambridge, 29-46.

Norman, D. (2010). Why Design Education Must Change, available at https://jnd.org/ why_design_education_must_change

Norman, D. and Klemmer, S. (2014). State of design: How design education must change, available at https://jnd.org/this_post_is_part_of

Oakley, B., Felder, R., Brent, R., and Elhajj, I. (2004). Turning Student Groups into Effective Teams. The Journal of Student Centered Learning, 2 (1), 9-34. 
Osborne, S.P., Radnor, Z., Nasi, G. (2012). A New Theory for Public Service Management? Toward a (Public) Service-Dominant Approach. American Review of Public Administration, 43(2), 135-158.

Ostrom, E., Parks, B., Whitaker, P., Percy, L. (1978). The Public Service Production Process: A Framework for Analyzing Police Services. Policy Studies Journal, 7, 381-389.

Papanek, V. (1971). Design for the Real World. Human Ecology and Social Change. Thames \& Hudson, London.

Prince, J. and Felder, M. (2006). Inductive Teaching and Learning Methods: Definitions, Comparisons, and Research Bases. Journal of Engineering Education, 95 (2), 123-138.

Rams, D. (c. 1976). Ten Principles for Good Design. In: Newson, A., Sugget, E., Sudjic, D. (Eds.) Designer Maker User. Phaidon, London, 2016, 185.

Rapp, W. (2014). Universal Design for Learning in Action: 100 Ways to Teach All Learners. Brookes Publishing, Baltimore, MD.

Seiler, K., Scarponi, A., Bölsterli, M. (2018). Hic et Nunc. In: Sachs, A. (Ed.) Social Design. Participation and Empowerment. Lars Müller Publishers, Zurich, 122-129.

Self, J., Evans, M., Jun, T., Southee, D. (2019). Interdisciplinary: Challenges and Opportunities for Design Education. International Journal of Technology and Design Education 2019, 29, 843-876. DOI: 10.1007/s10798-018-9460-5.

Sharp, B. (1980). Toward a New Understanding of Urban Services and Citizen Participation: The Coproduction Concept. The American Review of Public Administration, 14 (2), 105-118.

Shea, A. (2011). Designing for Social Change: Strategies for Community-Based Graphic Design. Princeton Architectural Press, NY.

Shostack, L. (1984). Designing Services that Deliver. Harvard Business Review, 62 (1), 133-139.

Smith, A., Sheppard, D., Johnson, W., Johnson, T. (2005). Pedagogies of Engagement: ClassroomBased Practices. Journal of Engineering Education, 94 (1), 87-101.

Whitaker, P. (1980). Coproduction: Citizen Participation in Service Delivery. Public Administration Review, 40 (5/6), 240-246.

Zeibote, Z., Putāns, R., Stacenko, S., Muravska T. (2018). How to Coproduce Public Services? Available at https://www.lu.lv/cets/news/t/45999

Zeibote, Z., Muravska T., Putāns, R. (2019). Improving Digitalization through Co-Creation: Case of the Citadel Project. Economy \& Business Journal, International Scientific Publications, 13 (1), 407-424.

WEB (a). Design Thinking Defined. https://designthinking.ideo.com

WEB (b). What is Service Design? https://trydesignlab.com/blog/what-is-service-design

WEB (c). Brainstorm Rules. https://www.designkit.org/methods/28

WEB (c). What is the framework for innovation? Design Council's evolved Double Diamond. https://www.designcouncil.org.uk/

WEB (d). Videointerview with Antonio Scarponi. https://www.hic-et-nunc.me

WEB (e) Description of the project. https://www.hic-et-nunc.me/overview

WEB (f) A historical coproduction excursus and the CITADEL Latvian Case. https://www.citadel-h2020.eu/news/historical-coproduction-excursus-and-citadel-latviancase

WEB (g) Study project Hic et Nunc. https://www.zhdk.ch/studienprojekt/f77a0e82-8f6c-4a13adeb-8d1c1e95dca5

WEB (h) Making digital public services more efficient, more accessible - and even safer. https://cordis.europa.eu/article/id/386887-making-digital-public-services-more-efficientmore-accessible-and-even-safer

Received June 19, 2020, revised September 9, 2020, accepted October 13, 2020 